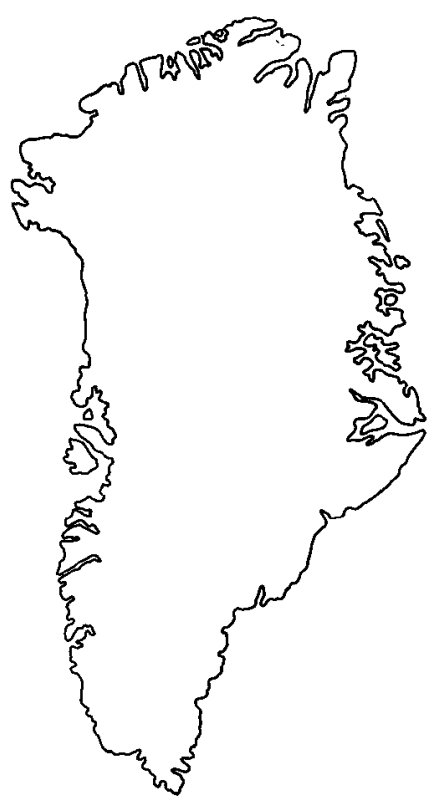

\title{
Silurian trilobites from Hall Land and Nyeboe Land, western North Greenland
}

\author{
Philip D. Lane \\ The Silurian trilobites described below are referred to 16 ge- \\ nera of which 1 is new (Nonix); 21 species-level taxa are \\ recognized of which 4 are new species (Kosovopeltis allaarti, \\ Proetus s.l. simus, Contracheirurus errator and Nonix sauro- \\ ter), 3 are previously-described species and 14 are left in open \\ nomenclature. The biostratigraphic and palaeogeographic \\ links implied by the trilobites are discussed after each taxon, \\ but the fauna as a whole is similar to Wenlock faunas from \\ Arctic Canada.
}

P.D.L., Department of Geology, University of Keele, Keele, Staffordshire ST5 5BG, U.K.

The Silurian trilobites described in this paper were collected in western North Greenland during Operation Grant Land, 1965-1966, a two-summer reconnaissance stratigraphic investigation of the northern Nares Strait region carried out by the Geological Survey of Canada and the Geological Survey of Greenland (see Dawes, this report). The fossiliferous samples were collected during 1965 in Hall Land by J. H. Allaart and P. R. Dawes and during 1966 by P. R. Dawes in Nyeboe Land, western North Greenland (fig. 1).

A summary of the geology of Hall Land and Nyeboe Land, including the biostratigraphic setting of the Silurian trilobites is given by Dawes \& Peel (this report). The stratigraphic unit designation used for the trilobites refers to the stratigraphic sections described in that paper. Fig. 1 shows the localities from which the material was obtained. Most of the material originates from a single locality in south-eastern Hall Land, on the northern slopes of Kayser Bjerg, from the upper part of the limestone sequence (unit 6D of Dawes \& Peel, this report), and this forms the subject of much of the paper and Plates 1-3. A concluding section deals with the small collections from six additional localities, some specimens from which are figured in Plate 4.

Regional reconnaissance mapping was the main activity of the 1965-1966 field work and no systematic fossil sampling of the stratigraphic sections which were examined was undertaken. Hence, fossil collections were small; but the trilobites nevertheless give pointcorrelations with sequences in other parts of North Greenland and in Arctic Canada. The large number of taxa left in open nomenclature reflects a cautious approach to formally naming species known only from a very small amount of material. But even some of the forms left in open nomenclature give strong indications of possible stratigraphic and palaeogeographic links.

Rapp. Gronlands geol. Unders. 121, 53-75 (1984) 


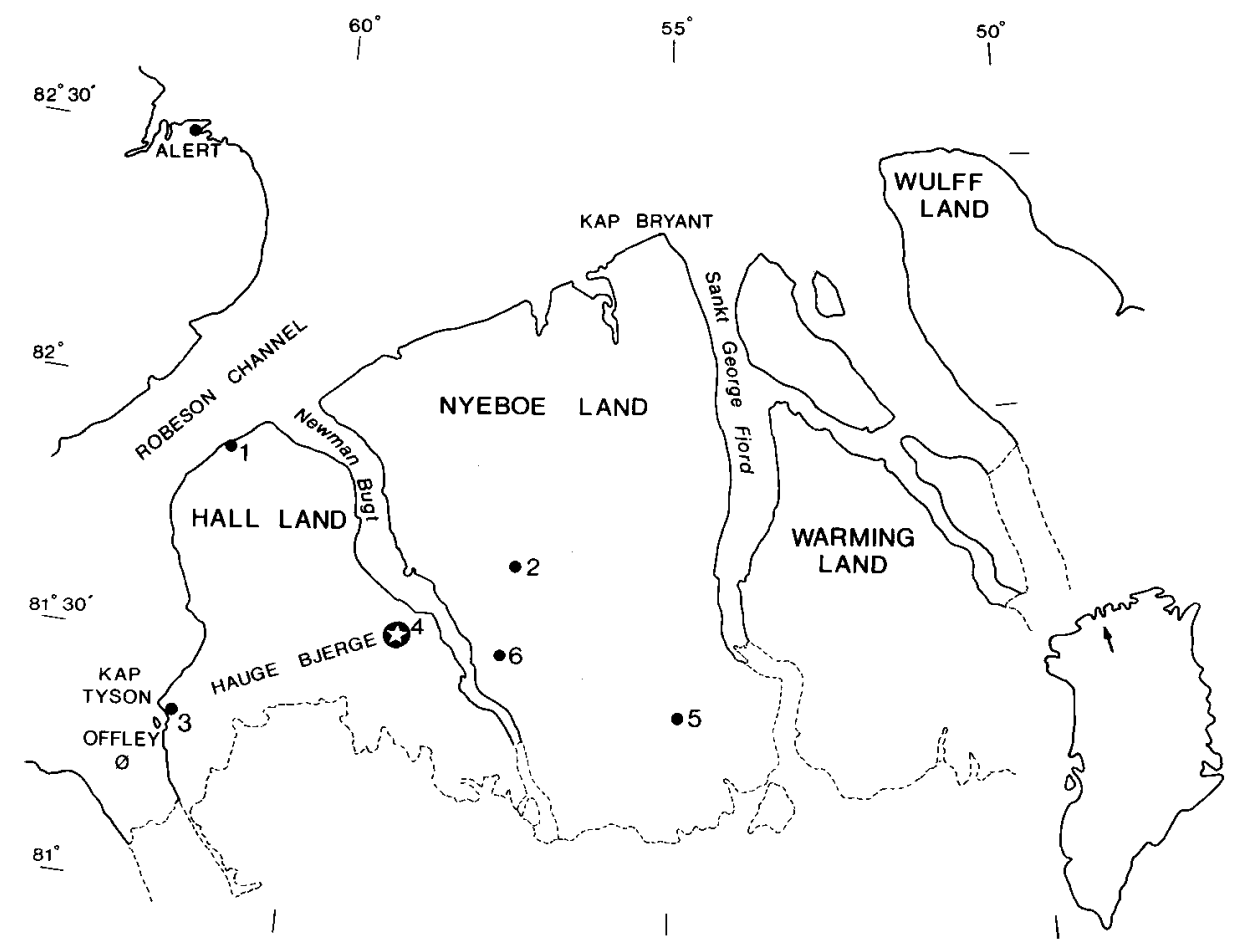

Fig. 1. Western North Greenland showing collecting localities for Silurian trilobites described in this paper. Most specimens were collected on the northern slopes of Kayser Bjerg (star). Material briefly discussed at the end of the paper was collected at: 1, Kap Ammen; 2, north-east Korsgaard Bjerg; 3, south-east of Kap Tyson; 4, northern slopes of Kayser Bjerg, but from platy limestones of unit 7 of Dawes \& Peel (this report), slightly east of the main collecting locality; 5, east side of Store Canyon; 6, south-west of Korsgaard Bjerg.

All the trilobites occur in carbonates from different parts of the Silurian platform sequence. These carbonates vary in character from pure, pale biosparites to dark indurated microsparites.

\section{Trilobites from Kayser Bjerg, Hall Land}

Trilobites described in this section were collected from unit 6D of Dawes \& Peel (this report), on the northern slopes of Kayser Bjerg (fig. 1). This unit is one of four recognized in a composite section in the eastern part of Hauge Bjerge, the mountainous belt of Silurian carbonate mounds which extends east-west across Hall Land (fig. 1). Unit 6D is a thick unit of light weathering, thick-bedded to massive limestones, forming the main massif of Kayser Bjerg. The unit can be referred to the Offley Island and Hauge Bjerge Formations of the Washington Land Group (Hurst, 1980).

Several species in the fauna from unit 6D are closely compared or conspecific with taxa described by Perry \& Chatterton (1977) and Chatterton \& Perry (1984) from Wenlock strata in the Canadian Arctic Archipelago and this age is therefore suggested for the Greenland material. 


\section{Systematic descriptions}

Family Styginidae Vogdes, 1890 [emend. Lane \& Thomas, 1983]

Discussion. For diagnosis and composition of this family see Lane \& Thomas, 1983, p. 156.

\section{Genus Ligiscus Lane \& Owens, 1982}

Type species. By original designation; Ligiscus arcanus Lane \& Owens, 1982, from the Llandovery (Telychian) or Wenlock (Sheinwoodian) of Washington Land, western North Greenland.

Diagnosis. See Lane \& Owens (1982, p. 46).

\section{Ligiscus sp.}

Plate 1, fig. 1a-c

Figured material. MGUH 16.291 (cephalon; GGU 82640).

Discussion. A single small cephalon is referred to Ligiscus. Compared to the type species it is more convex sagittally, has a similar cranidial muscle scar pattern, although all scars are more weakly impressed and the glabellar scars are more distant from the axial furrow, a glabella which is everywhere proportionately wider, an axial furrow which is indistinct and which ends anteriorly at a tiny but distinct anterior pit, and an anterior section of the facial suture which describes a smooth curve which is convex outwards.

There is further discussion of this cephalon under Opsypharus sp. below.

\section{Genus Opsypharus Howells, 1982}

Type species. By original designation; Illaenus (Bumastus) Maccallumi Salter, 1867, from the Llandovery (Aeronian), near Girvan, Scotland.

Diagnosis. See Howells (1982, p, 10).

Opsypharus sp.

Plate 1, figs $2-8$

1977 Indeterminate illaenid; Perry \& Chatterton, p. 288, pl. 3, figs 1-7.

Figured material. MGUH 16.292 (cranidium; GGU 82645); MGUH 16.293,4 (free cheeks; GGU 82654, 82640); MGUH 16.295-7 (pygidia; GGU 82646, 82652); MGUH 16.298 (five fragmentary thoracic segments and pygidium; GGU 82651).

Other material. GGU 82642.1, 82654.1 (free cheeks); GGU 82637.1, 82639.1, 82648.1, 82652.1, 82654.2 (pygidia).

Discussion. The low convexity of the cranidium and well-developed holcos of the larger pygidia indicate the generic assignment. Pygidia with sagittal lengths from 5 to $26 \mathrm{~mm}$ (estimated) are present, the smaller ones having the holcos much less well developed except anterolaterally. 
The overall morphology of the cranidium and free cheek of the Hall Land material appears to differ in no significant respects from the material described by Perry \& Chatterton (1977). In minor respects there are differences; the Greenland material has a less distinct anterior pit, lacks well-developed terrace ridges on the dorsal surface of the free cheek, and possesses a distinctive sculpture of pits, each of which houses a distinct median tubercle. The Canadian material appears only to have pits. The pygidia in the two sets of material have similar proportions.

The difficulty of placing small amounts of fragmentary effaced material is well illustrated by these specimens. It is not impossible that the cephalon described above as Ligiscus sp. is a small cephalon of this Opsypharus sp., all the obvious differences being due to the differences in size. I have taken the present decision, however, since Ligiscus sp. lacks both the concave areas on the free cheek seen both in Opsypharus sp. and in small specimens of the type species, and it does not possess the striking pit-with-tubercle sculpture. Additionally, Ligiscus sp. is much more convex and although this could be a feature of a small specimen in a growth series, small cranidia of $O$ psypharus maccallumi (compare Howells 1982, pl. 2, figs $8 \mathrm{a}, 10 \mathrm{~b})$ have similar convexity to large examples.

\section{Genus Kosovopeltis Šnajdr, 1958}

Type species. Kosovopeltis svobodai Šnajdr, 1958, from the Ludlow of Czechoslovakia.

Kosovopeltis allaarti sp. nov.

Plate 1, figs 9-16

Derivation of name. For the late Jan H. Allaart, long-serving GGU geologist, who participated in the 1965 field season of Operation Grant Land.

Holotype. MGUH 16.303 (cranidium; GGU 82654).

Figured paratypes. MGUH 16.300-1 (cranidia; GGU 82640, 82641); MGUH 16.299 (hypostome; GGU 82654); MGUH 16302, 4-6 (pygidia; GGU 82642, 82636, 82640, 82642).

Other material. GGU 82640.1, 82656.1 (cranidia), 82642.2, 82643.1 (pygidia).

Diagnosis. Glabella distinctly waisted, lacking any parallel-sided portion. From waist (which is one-third distance from posterior margin), glabellar width increases evenly backwards and forwards as far as opposite $3 \mathrm{G}$; frontal lobe markedly wider and laterally well rounded. Occipital ring very short (exsag.) laterally. $1 \mathrm{G}$ lunate and least well impressed. $2 \mathrm{G}$ short and slit-like with adaxial margin well impressed, slightly nearer $3 \mathrm{G}$ than posterior margin of $1 \mathrm{G}$ and at about its own width distant from axial furrow. $3 \mathrm{G}$ also slit-like, with adaxial margin in same exsagittal line as $2 \mathrm{G}$, deeply impressed for twice width of $2 \mathrm{G}$ and connected to axial furrow by shallow wider (tr.) area. Preglabellar furrow distinct over lateral one-third of frontal lobe, not present medially. Pygidium with little convexity and with seven pairs of ribs, and a terminally bifid median rib. Axis about one-quarter, and doublure about twothirds of total sagittal length. 
Description. In addition to the characters given in the diagnosis, the lateral muscle impression is almost circular and lies adjacent to the narrowest part of the glabella. It is well impressed, especially marginally. $1 \mathrm{~L}$ is of similar length to $2 \mathrm{~L}$ and $3 \mathrm{~L}$, as is frontal lobe laterally. Occipital muscle impression short and wide, lunate and convex-backward. Palpebral lobe reaches from opposite mid lateral muscle impression to mid $2 \mathrm{~L}$, semicircular in outline. Eye ridge distinct. Axial furrow everywhere well impressed. Overall convexity of cranidium moderate. Sculpture everywhere (except in furrows and muscle impressions) of densely-packed, short, curved ribs, with additionally irregular pits on the fixed cheek.

Two small cranidia (sagittal lengths 2.4 and $2.6 \mathrm{~mm}$ ) and one small pygidium (sagittal length $1.7 \mathrm{~mm}$ ) have been found. The cranidia show that the $3 \mathrm{G}$ scar is connected to the axial furrow, although it is more deeply impressed adaxially. The pygidium has a length:width ratio of 1:2 as opposed to 4:3 in the largest pygidium known (sagittal length $c$. $23 \mathrm{~mm}$ ). All these small elements have a sculpture of relatively coarse tubercles, with no sign of the adult sculpture.

Discussion. The $2 \mathrm{G}$ and $3 \mathrm{G}$ are particularly distinctive, being slit-like and deeply impressed. Although some other species of Kosovopeltis and some of Planiscutellum have $2 \mathrm{G}$ and $3 \mathrm{G}$ of a similar shape to this, they are generally weakly impressed; in those forms the glabellar outline is not distinctly waisted and the overall convexity is much less. However, the unique specimen described by Šnajdr (1960, p. 78, pl. 36, fig. 7) as Kosovopeltis tchernychevae nov. sp. from an unknown horizon on the River Vagran, Urals, U.S.S.R. is exceedingly similar to $K$. allaarti. This fragmentary cranidium has much the same outline and proportions as $K$. allaarti but differs in details. It appears to lack (even laterally) any preglabellar furrow and has a rather more sharply-rounded lateral part of the frontal glabellar lobe. It also shows a relatively longer $1 \mathrm{~L}$ and abaxial part of the occipital ring, and terrace ridges which are more distinct and regular.

The pygidium of $K$. allaarti could be confused with species of Meroperix which are similar in general convexity, outline and proportion, and which occur in rocks of similar age in other parts of the Arctic. However, whereas the ribs of the former widen and become less distinct distally, those of Meroperix narrow towards the margin after an adaxial widening. In addition, the median rib of Meroperix is bifid almost to the axis, and at the same size pygidium is relatively wider than long.

Family Proetidae Salter, 1864

Subfamily Proetinae Salter, 1864

Genus Proetus Steininger, 1831

Type species. By original designation; Calymmene concinna Dalman, 1827, from the Wenlock (Mulde Formation) of Djupvik, Gotland.

Diagnosis. See Owens (1973, p. 8).

Proetus s.l. simus sp. nov.

Plate 2, figs 1-7

Derivation of name, Latin 'pug-nosed'.

Holotype. MGUH 16.308 (cephalon; GGU 82636). 
Figured paratypes. MGUH 16.307 (cephalon; GGU 82636); MGUH 16.312 (free cheek; GGU 82650); MGUH 16.309 (seven thoracic segments and pygidium; GGU 82640); MGUH 16.310, 11, 13 (pygidia; GGU 82640, 82671 ( 2 specimens)).

Other material. GGU 82640.2, 82650.1 (cephala), 82634.1, 82640.3 (cranidia), 82640.4 (free cheek), $82640.5,82650.2$ (pygidia).

Diagnosis. Cephalon very convex. Glabella short and wide, subquadrate. Genal spine short. Pygidium with at best very weakly-developed 'border' (see discussion below). Axis with 6-7 rings; pleural areas with 4-5 pairs of ribs, only the anterior pair reaching to near margin. Sculpture of cephalon and pygidium of relatively large and scattered granules; free cheek additionally finely pitted.

Discussion. I doubt that the weak submarginal structure developed in pygidia of this type is the homologue of the true border developed in some other trilobite groups. This is because it widens backwards, which is a most unusual feature, and sometimes the axis interrupts or overlies it. In no other trilobite does a clearly-developed axis overlie an undoubted border. A pygidial marginal structure, which probably also is not a true border occurs in some raphiophorids (see Thomas, 1978, pl. 14).

Proetus (s.l.) simus belongs to a well-known group of species of Wenlock and Ludlow age. The cephalon is readily distinguished from perhaps the morphologically closest forms $-P$. (s.l.) granulatus Lindström, 1885 (see Owens, 1973, p. 22, pl. 2, fig. 3) and P. (Lacunoporaspis) oppidanus (Thomas, 1978, p. 38, pl. 10, figs 1-8; text-fig. 5) by its short and wide glabella, overall greater convexity, genal spine which is intermediate in length between the other two forms, and the type of granulation - that of the former consists of large and densely-packed granules, the latter lacks large distinct granules. The pygidium of $P$. (L.) oppidanus is virtually identical; it often has a little better-developed 'border', although this character tends to be variably developed in all species.

Another similar form is the cephalon figured by Perry \& Chatterton (1977, pl. 1, figs 1, 2) as Proetus (s.l.) sp. from the late Wenlock of Arctic Canada. The forms from these two areas may well be conspecific but differences in preservation preclude certainty. Additionally, it is likely that the pygidia referred to Proetus (s.1.) cf. granulatus Lindström by these two authors in the same paper ( $\mathrm{pl}$. 1, figs 9-14, 20) should be associated with the cranidium mentioned above. Again, differences between the two sets of material are slight; the pleural and interpleural furrows of the Canadian material are a little better impressed.

Proetus cf. granulatus of Schrank (1972, pl. 1, figs 2-5 only) from an erratic of presumed Wenlock age from Germany, and the pygidia figured as Proetus (Coniproetus) and $P$. (?Coniproetus) by Perry \& Chatterton $(1977$, pl. 68 , figs $10,11,31)$ from the Wenlock of the Mackenzie Mountains, north-west Canada may also be conspecific with $P$. s.l. simus.

A Wenlock or lower Ludlow age is indicated by the appearance of this form.

Proetus (s.1.) sp.

Plate 2, fig. 9

Figured material. MGUH 16.315 (pygidium; GGU 82656).

Other material. GGU 82634.2 (pygidium). 
Discussion. This type of pygidium is distinctive in possessing few (4-25) pleural ribs of which only the anterior three are at all distinct, and all of which end remote from the margin by a relatively wide concave marginal zone. In general form this pygidium resembles that figured by Perry \& Chatterton (1977, pl. 1, figs 3, 4).

\section{Genus Hedstroemia Přibyl \& Vaněk, 1978}

Type species. By original designation; Proetus delicatus Hedström, 1923, from the late Wenlock (Halla Formation) of Gotland.

\section{Hedstroemia sp.}

Plate 2, fig. $8 \mathrm{a}, \mathrm{b}$

Figured material. MGUH 16.314 (cranidium; GGU 82634).

Discussion. A single fragmentary cranidium resembles $H$. delicata but has better developed occipital lobes. It is too poorly preserved for further identification. Forms with this general morphology are typical of Wenlock and Ludlow rocks.

\section{Family Harpedidae Hawle \& Corda, 1847 \\ Genus Scotoharpes Lamont, 1948}

Type species. By monotypy; Scotoharpes domina Lamont, 1948, from the late Llandovery (Telychian) of Lothian, Scotland.

Diagnosis. See Norford (1973, p. 11).

\section{Scotoharpes sp.}

Plate 2, fig. 18

Figured material. MGUH 16.324 (cephalon; GGU 82644).

Discussion. A single cephalon possesses the features typical of Scotoharpes. A useful character used in distinguishing species within the genus is the number of pits sagittally in the cheek roll and in the brim. In this specimen these counts are around 20 and 40 , but the number is difficult to ascertain due to their rather irregular arrangement. These figures agree with $S$. sinensis (Grabau; see Lu 1962, p. 171, pl. 1, figs 7, 8) but this species is described as having a flat brim not dorsally concave and appears to have better developed caecae. Also, as compared with $S$. sinensis the eye is a little farther forward, and $1 S$ originates adjacent to the axial furrow a little farther back (at one-third rather than one-half glabellar length). $S$. loma (Lane, 1972) differs from this specimen in having a wider brim, a more tapering glabella with less transverse convexity and more dorsally-concave brim prolongation. It is likely that a new species is represented by the specimen. 
Family Cheiruridae Hawle \& Corda, 1847

Subfamily Cheirurinae Hawle \& Corda, 1847

Genus Contracheirurus Chatterton \& Perry, 1984

Type species. By original designation; Contracheirurus zuvegesi Chatterton \& Perry, 1984, p. 17, from the Delorme Formation (early Wenlock) of north-western Canada.

Diagnosis. See Chatterton \& Perry (1984, p. 17).

\section{Contracheirurus errator sp. nov.}

Plate 2, figs 12-17

1984 Contracheirurus n. gen. n. sp. A, Chatterton \& Perry, p. 19, pl. 1, figs 19-22, pl. 35, figs 1-15.

Derivation of name. Latin 'wanderer', referring to the wide distribution of this species.

Holotype. MGUH 16.318 (pygidium; GGU 82640).

Figured paratypes. MGUH 16.319-20 (cranidia; GGU 82640); MGUH 16.321 (hypostome; GGU 82640); MGUH 16.322,23 (pygidia; GGU 82640).

Other material. GGU 82640.6-9, 82642.3-4, 82650.3 (cranidia), 82640.10-11 (hypostomes), 82640.12, 82650.4 (thoracic segments).

Diagnosis. A species of Contracheirurus with $2 \mathrm{~S}$ and $3 \mathrm{~S}$ long, and joined across sagittal line by weak depression; eye extends from opposite anterior of $2 \mathrm{~L}$ to mid $3 \mathrm{~L}$. Pygidial axis with three rings and terminal piece, anterior inter-ring furrow with distinct non-functional halfring. Pygidial spines relatively long, slender and tubular, third (posterior) pair, least curved.

Discussion. A lengthy description is deemed not necessary since the characters in the diagnosis serve readily to distinguish $C$. errator from the type species.

Chatterton \& Perry (1984) referred their Contracheirurus n. sp. A to their new genus since although there is a great difference in the morphology of the pygidial spines, the cranidia are practically identical. The great similarity of the cranidia of the two species is emphasised by comparison of their plate 1, fig. 1 with Plate 2, fig 12 here.

A slight difference may be noted between the Canadian and Greenland examples of $C$. errator, since the posterior pygidial spines of the former sometimes are only slightly curved, and in some the spines are longer. I prefer to consider this as an example of intraspecific variation, since in all other characters the pygidia are in agreement. The pygidia of cheirurine species often show significant variation.

In north-western Canada, $C$. errator occurs in rocks of late Wenlock to possibly early Ludlow age.

Subfamily Sphaerexochinae Öpik, 1937; emend. Lane \& Owens, 1982 Diagnosis. See Lane \& Owens (1982, p. 52). 
Genus Sphaerexochus Beyrich, 1845

Type species. By monotypy; Sphaerexochus mirus Beyrich, 1845, originally described from the Wenlock of Czechoslovakia.

Diagnosis. See Lane (1971, p. 53).

\section{Sphaerexochus dimorphus Perry \& Chatterton, 1977 \\ Plate 3, figs 1-5}

1977 Sphaerexochus dimorphus sp. nov., Perry \& Chatterton, p. 292, pl. 2, figs 1-21, pl. 3, figs 8-15.

Figured material. MGUH 16.325, 7 (cranidia; GGU 82640, 82634), MGUH 16.328 (hypostome; GGU 82642), MGUH 16.326 (thoracic segment; GGU 82650); MGUH 16.329 (pygidium; GGU 82640).

Other material. GGU 82638.1, 82640.13, 82642.5, 82652.2-3 (cranidia), 82634.3-4 (thoracic segments).

Discussion. The species was erected for material of late Wenlock age from Baillie-Hamilton Island in the Canadian Arctic, in which the only character diagnostic of the taxon (spines on the pygidial axial rings) is not present in all specimens. Thomas $(1981, \mathrm{p} .63)$ pointed out that the pygidia of $S$. dimorphus which lacked these spines were otherwise indistinguishable from those of the type species, as were the cranidia.

Perry \& Chatterton's (1977) material did not include thoracic segments or hypostomes, both of which are figured here. The thoracic segments have axial ring spines like those of the pygidia. The hypostome is of typical Sphaerexochus construction, and differs from the single figured hypostome of $S$. mirus in being $30 \%$ wider than long (it is $50 \%$ wider than long in the type species). This difference may be used as a specific character, but hypostomes associated with $S$. centeo Lane \& Owens (1982, p. 53, pl. 4, figs 1-10, 12-15) have a variety of width to length proportions varying from width being about $50 \%$ greater than length to only $25 \%$, or even $17 \%$ if the hypostome questionably referred to this species (Lane \& Owens 1982, pl. 4, fig. 11) is conspecific.

In the light of this evidence, it may be that dimorphus is at most only subspecifically distinct from mirus.

\section{Family Encrinuridae Angelin, 1854 \\ Genus Encrinurus Emmrich, 1844}

Type species. Entomostracites punctatus Wahlenberg, 1818, p. 32, pl. 2, fig. 1* from the Wenlock (?Högklint Formation) of Gotland. See ICZN Opinion 537 (1959).

Diagnosis. See Thomas (1981, p. 63).

\section{Subgenus Fragiscutum Whittington \& Campell, 1967}

Type species. By original designation; Fragiscutum rhytium Whittington \& Campbell, 1967, from late Wenlock and Ludlow of Maine, U.S.A. 


\section{?Fragiscutum sp. \\ Plate 2, fig. 11}

Figured material. MGUH 16.317 (pygidium; GGU 82637).

Other material. MGUH 82643.2 (cranidium), 82646.1 (free cheek), 82646.2 (pygidium).

Discussion. This material resembles that figured by Perry \& Chatterton (1977, pl. 4, figs 1-14, 25, 26) as Encrinurus (Fragiscutum) sp. from the late Wenlock of Arctic Canada. With so little material to hand it is not possible to decide whether or not the forms are conspecific.

Family Calymenidae Burmeister, 1843

Genus Calymene Brongniart, 1822

Type species. Calymene blumenbachii Brongniart, 1822, from the late Wenlock of England.

\section{Calymene sp.}

Plate 2, fig. 10

Figured material. MGUH 16.316 (cranidium; GGU 82640).

Discussion. A fragmentary cranidium is the only representative of the family in the fauna. Its buttressed $2 \mathrm{~L}$ allows reference to the genus, but no further determination is possible. A sculpture of coarse, scattered granules set amongst smaller ones can be seen.

Family Lichidae Hawle \& Corda, 1847

Subfamily Lichinae Hawle \& Corda, 1847

Genus Nonix gen. nov.

Derivation of name. Greek 'nine' and 'grub' referring to the number of pygidial spines.

Diagnosis. Pygidium resembles Dicranopeltis but has an extra pair of lateral spines, and a posterior median spine, making nine in all.

Nonix sauroter sp. nov.

Plate 3, figs 9, 11-14

Derivation of name. Greek 'spike at the butt end'.

Holotype. MGUH 16.338 (pygidium; GGU 82641).

Figured paratypes. MGUH 16.335,6 (pygidia; GGU 82676, 82637); MGUH 16.334, 7, (cranidia; GGU $82656,82634)$.

Other material. GGU 82650.5 (pygidium). 
Description. Cranidium rounded anteriorly with much greater convexity sagittally than transversely. Occipital ring wide (sag.) narrowing rapidly abaxially. Longitudinal furrows distinct, posteriorly remote from occipital furrow, delimiting a median glabellar love which initially expands gently forwards and then rapidly; in dorsal view, anterior margin of this lobe projects markedly in front of bullar lobes. $1 \mathrm{~L}$ subangular, the posterolateral corner the most abaxial point, not delimited adaxially. 1S distinct, running a little abaxially forward from the transverse direction. Bullar lobe almost parallel-sided over most of its length, rounded posteriorly and rounded-angular in front, with greater convexity than adjacent part of median lobe, especially in the smallest specimen. Axial furrow clearly defined although less so than the furrows of the glabella. Anterior section of facial suture parallel to anterior part of axial furrow; posterior section diverges strongly away from posterior part of axial furrow. Palpebral lobe opposite a line about one-third way forward along bullar lobe. Surface (except in furrows) irregularly and coarsely granulose.

Pygidium excluding spines a little wider than long. Axis a little more convex than general pygidial convexity, anteriorly two-thirds width of whole pygidium (excluding spines), narrowing gently at first and then a little more so, terminating indistinctly and bluntly at about half distance to posterior (excluding spines). Anteriorly, axis bears a single distinct inter-ring furrow, behind which lies a less distinct ankylosed articulating half ring. Behind axis is a much less convex triangular area, anterolaterally weakly delimited, posteriorly confluent with pleural areas. Axial furrow laterally distinct. Pleural areas almost flat, with three pairs of distinct pleural and interpleural furrows. Margin with 4 lateral pairs and a posterior median spine, all of which are slender, gently curved and all terminally more or less posteriorly directed. Doublure occupies about one-third of sagittal length of pygidium (excluding spines) posteriorly, and narrows anteriorly. Sculpture like that of cranidium.

Discussion. Nonix is one of those rare lichids which appears to have failed to release into the thorax what is normally its posterior segment. This feature is also seen in Nitidulopyge (Přibyl \& Erben, 1952) and a species of Uralichas (see Vaněk 1959, p. 107, pl. 1, fig. 2) if the pygidium has there been correctly assigned. There would appear to be an argument for referring to material to Dicranopeltis especially as the axial and pleural areas of the pygidium are so similar. But I consider that the combination of this rare (for lichids) character and the presence of a median spine warrant the recognition of a new genus, even though the cephalon which $I$ have associated with the pygidium on the grounds of similarity of sculpture is hardly distinguishable from Dicranopeltis.

Subfamily Ceratarginae Tripp, 1957

Genus Dicranogmus Hawle \& Corda, 1847

Type species. By original designation; Dicranogmus pustulatus Hawle \& Corda, 1847 (=Lichas simplex Barrande, 1846) from the late Silurian of Czechoslovakia.

Diagnosis. See Perry \& Chatterton (1977, p. 308). 
Dicranogmus aff. D. skinneri Perry \& Chatterton, 1977

Plate 3, figs 6, 8, 10

Figured material. MGUH 16.330 (cephalon; GGU 82640); MGUH 16.332 (cranidium; GGU 82654); MGUH 16.331 (hypostome; GGU 82649).

Other material. GGU 82640.14,15 (cranidia).

Discussion. The cephalon shows the small, isolated occipital lobes and longitudinal glabellar furrows dying out anteriorly, which are features typical of the genus. Compared to Perry \& Chatterton's species it has slightly coarser tuberculation, and the furrows on the cranidium are narrower and less well impressed. In overall proportion, however, the two forms are very similar.

The hypostome I have ascribed to the form because of the similarity of sculpture, has a simple unforrowed trapezoidal middle body, and in these respects and in its general outline resembles that of $D$. skinneri.

\section{Ceratargine hypostome \\ Plate 3, fig. 7}

Figured material. MGUH 16.333 (hypostome; GGU 82649).

Discussion. A small hypostome has a sculpture of small pits, and lacks the coarse tuberculation seen in all the other ceratargine elements in the fauna. In general form it resembles the hypostome of species of Acanthopyge, although it is not impossible that it should be associated with the Dicranogmus material described above.

\section{Trilobites from other localities}

Silurian trilobites were collected from six further localities in Hall Land and Nyeboe Land (fig. 1). The amount of material is small and does not warrant formal taxonomic treatment. Stratigraphic units indicated in parentheses are described by Dawes \& Peel (this report).

\section{Locality 1. Kap Ammen, northern Hall Land (unit 1D)}

MGUH 16.343 (Pl. 4, fig. 4; GGU 82489) is the only trilobite from this locality. It is a large weathered and fragmentary pygidium which can be compared to Opoa adamsi. In view of the poor condition of the specimen, and the fact that the distribution of forms like this could be strongly facies controlled, it is not possible to assign a date to the specimen.

\section{Locality 2. North-east of Korsgaard Bjerg, central Nyeboe Land (unit 4A)}

At this locality, Opoa adamsi (MGUH 16.342; Pl. 4, fig. 5; GGU 83410), Meroperix ataphrus (MGUH 16.339, 40; Pl. 4, figs 1, 2; GGU 83409, 83408) and Chiozoon cf. C. cowiei (MGUH 16.341; Pl. 4, fig. 3; GGU 83405) occur which by comparison with faunas from Kronprins Christian Land (Lane, 1972) indicate an age around the Llandovery-Wenlock boundary. 
Locality 3. South-east of Kap Tyson, south-west Hall Land (unit 10A)

A single pygidium can be referred to encrinurinid sp. indet. (MGUH 16.346; Pl. 4, fig. 8a, b; GGU 82591).

\section{Locality 4. Northern slopes of Kayser Bjerg, south-east Hall Land (unit 7)}

Good cranidia of Sphaerexochus occur, together with poor specimens of Encrinurus. I have referred the cranidia to $S$. cf. $S$. dimorphus (MGUH 16.344; Pl. 4, fig. 6a; b; GGU 82709 ) since it is impossible to distinguish cranidia of that species from those of $S$. mirus. In any event, a Wenlock or Ludlow age is indicated. This locality lies slightly east of the main locality at Kayser Bjerg.

\section{Locality 5. East side of Store Canyon, southern Nyeboe Land (unit 13E)}

In addition to indeterminate encrinurids, good material of an effaced styginid occurs. I have assigned it to Bumastus sp. (MGUH 16.347-9; Pl. 4, figs 9-11; GGU 82248, 82246, 82247). It is similar to, and may yet prove conspecific with one of the forms which occur in the Wenlock and Ludlow of Gotland. Amongst the characters shared by these forms are the extreme effacement of cephalic and pygidial furrows and on most specimens like those to hand, it is not possible to make out the positions of cranidial muscle scars. In this group of forms, large collections will be required to allow the erection of species, and for this reason I have chosen not to formally name this material.

\section{Locality 6. South-west of Korsgaard Bjerg, south-west Nyeboe Land (unit 12A)}

A very well-preserved pugidium (with five articulated thoracic segments) was collected here which is compared to Ligiscus arcanus Lane \& Owens, 1982 (MGUH 16.345; Pl. 4, fig. 7; GGU 82125). The age indicated by this, and by a fragmentary cranidium of Chiozoon is late Llandovery or early Wenlock.

Acknowledgements. For helpful comments which have improved an earlier draft of this manuscript I thank B. D. E. Chatterton, G. J. Helbert, D. J. Holloway, R. M. Owens, Derek J. Siveter and A. T. Thomas. Thanks are also due to P. R. Dawes and J. S. Peel for the stratigraphic information. Type and figured specimens (MGUH prefix) are deposited in the Geological Museum, Copenhagen.

\section{References}

Angelin, N. P. 1854: Palaeontologia Scandinavia. I. Crustacea formationis transitionis. 2, 21-92. Lund. Barrande, J. 1846: Notice préliminaire sur le Systême Silurien et les trilobites de Bohême. 97 pp. Leipsic. Beyrich, E. 1845: Ueber einige böhmischen Trilobiten. 47 pp. Berlin.

Brongniart, A. 1822: Histoire naturelle des Crustacés fossiles, sous les rapport zoologiques et géologiques. Savoir: les Trilobites par Alexandre Brongniart. Les Crustacés proprement dits par A.-G. Desmarest. 154 pp. Paris.

Burmeister, H. 1843: Die Organisation der Trilobiten, aus ihren lebenden Verwandten entwickelt; nebst einer systematischen Übersicht aller zeither beschreibenen Arten. 147 pp. Berlin.

Chatterton, B. D. E. \& Perry, D. G. 1984: Silurian cheirurid trilobites from the Mackenzie Mountains, northwestern Canada. Palaeontographica A, 184(1), 1-78, 35 pl.

Dalman, J. W. 1827: Om palaeaderna, eller de sa kallade trilobiterna. K. svenska VetenskAkad. Handl. (for 1826), 113-152, 226-294.

5 Rapport nr. 121 
Dawes, P.R. this report: Operation Grant Land 1965-1966; a geological exploration programme in Ellesmere Island and North Greenland. Rapp. Grønlands geol. Unders. 121, 5-17.

Dawes, P. R. \& Peel, J. S. this report: Biostratigraphic reconnaissance in the Lower Palaeozoic of western North Greenland. Rapp. Grønlands geol. Unders. 121, 19-51.

Emmerich, H. F. 1844: Zur Naturgeschichte der Trilobiten. 28 pp. Meiningen.

Hawle, I. \& Corda, A. J. C. 1847: Prodrom einer Monographie der bömischen Trilobiten. Prague: Abh. K. böhm. Ges. Wiss. 176 pp.

Hedström, H. 1923: Contributions to the fossil fauna of Gotland. I. Sver. geol. Unders. Afh. C, 316, $1-24$.

Howells, Y. 1982: Scottish Silurian trilobites. Monogr. palaeontogr. Soc. 1-76. London.

Hurst, J. M. 1980: Silurian stratigraphy and facies distribution in Washington Land and western Hall Land, North Greenland. Bull. Gronlands geol. Unders. 138, 95 pp.

Lamont, A. 1948: Scottish Dragons. Quarry Managers J. 31, 531-535.

Lane, P. D. 1971: British Cheiruridae (Trilobita). Monogr. palaeontogr. Soc. 1-95. London.

Lane, P. D. 1972: New trilobites from the Silurian of north-east Greenland, with a note on trilobite faunas in pure limestones. Palaeontology 15, 336-364.

Lane, P. D. \& Owens, R. M. 1982: Silurian trilobites from Kap Schuchert, Washington Land, western North Greenland. Rapp. Grønlands geol. Unders. 108, 41-69.

Lane, P. D. \& Thomas, A. T. 1983: A review of the trilobite suborder Scutelluina. Spec. Pap. Palaeont. 30, $141-160$.

Lindström, G. 1885: Förteckning på Gotlands siluriska crustacéer. Öfvers K. VetenskAkad. Förh. 6, $37-100$.

Lu, Yen-Hao 1962: Restudy on Grabau's types of three Silurian trilobites from Hupeh. Acta palaeont. sinica. 10, 158-174. (In Chinese; English summary, 167-174).

Norford, B. S. 1973: Lower Silurian species of the trilobite Scotoharpes from Canada and N. W. Greenland. Bull. geol. Surv. Can. 222, 3-32.

Öpik, A. A. 1937: Trilobiten aus Estland. Acta Comment. Univ. Tartu (A), 32, 1-163.

Owens, R. M. 1973: British Ordovocian and Silurian Proetidae (Trilobita). Monogr. palaeontogr. Soc. $98 \mathrm{pp}$. London.

Perry, D. G. \& Chatterton, B. D. E. 1977: Silurian (Wenlockian) trilobites from Baillie-Hamilton Island, Canadian Arctic Archipelago. Can. J. Earth Sci. 14, 285-317.

Přibyl, A. \& Erben, H. K. 1952: Über einige neue oder wenig bekannte Acanthopyginae (Tril.) des böhmischen und des deutschen Devons. Paläont. Z. 26, 141-174.

Přibyl, A. \& Vaněk, J. 1978: Studie zu einigen neuen Trilobiten der Proetidae-Familie. Acta Univ. Carol. (Geol.) 1978, 163-182.

Salter, J. W. 1864; 1867: A monograph of the British trilobites from the Cambrian, Silurian and Devonian formations. Monogr. palaeontogr. Soc. 1, 1-80 (1864); 4, 177-214 (1867). London.

Schrank, E. 1972: Proetacea, Encrinuridae und Phacopina (Trilobita) aus silurischen Geschieben. Geologie 76, 1-117.

Šnajdr, M. 1958: Několik nových rodŭ trilobitŭ z čekedě Scutelluidae. Vest ústřed Úst geol. 33, 177-184.

Šnajdr, M. 1960: Studie o celedi Scutelluidae (Trilobitae). Rozpr. ústred. Úst. geol. 26, 11-221. (English summary, 227-265).

Steininger, J. 1831: Observations sur les fossiles du Calcaire intermédiare de l'Eifel. Mém. Soc. géol. Fr. 1, 331-371.

Thomas, A. T. 1978; 1981: British Wenlock trilobites. Monogr. palaeontogr. Soc. 1, 1-56 (1978); 2, 57-99 (1981). London.

Tripp, R. P. 1957: The classification and evolution of the superfamily Lichacea (Trilobita). Geol. Mag. 94, 104-122.

Vančk, J. 1959: Celed Lichaidae Hawle et Corda, 1847 ze stredoceskeho starsiho Paleozoika (Trilobitae). Bohemia Centralis A 1, 80-168. 
Vogdes, A. W. 1890: A bibliography of Palaeozoic Crustacea from 1698 to 1889, including a list of North American species and a systematic arrangement of genera. Bull. U. S. geol. Surv. 63, 1-177. Wahlenberg, G. 1818: Petrificata telluris Suecanae. Nova Acta R. Soc. Scient. Upsala 8, 1-116.

Whittington, H. B. \& Campbell, K. S. W. 1967: Silicified Silurian trilobites from Maine. Bull. Mus. comp. Zool. Harv. 135, 447-482. 


\section{Plate 1}

All specimens are from the north side of Kayser Bjerg, Hall Land, western North Greenland.

\section{Ligiscus sp.}

Fig 1a-c. MGUH 16.291. Cephalon; dorsal, right-lateral and anterior views. $\times 5$.

\section{Opsypharus sp.}

Fig. 2. MGUH 16.292. Cranidium; plan view. $\times 1$.

Fig. 3. MGUH 16.293. Right free cheek; plan view. $\times 1$.

Fig. 4. MGUH 16.294. Right free cheek; plan view. $\times 3$.

Fig. 5. MGUH 16.295. Pygidium; dorsal view. $\times 4$.

Fig. 6. MGUH 16.296. Pygidium; dorsal view. $\times 3$.

Figs 7a, b. MGUH 16.297. Pygidium; dorsal and right-lateral views. $\times 1.5$.

Fig. 8. MGUH 16.298. Fragmentary five thoracic segments and pygidium; dorsal view. $\times 2$.

\section{Kosovopeltis allaarti sp. nov.}

Fig. 9. MGUH 16.299. Paratype hypostome; dorsal view. $\times 8$.

Fig. 10. MGUH 16.300. Paratype small cranidium; dorsal view. $\times 8$.

Fig. 11. MGUH 16.301. Paratype cranidium; dorsal view. $\times 3$.

Fig. 12. MGUH 16.302. Paratype pygidium; dorsal view. $\times 3$.

Figs 13a, b. MGUH 16.303. Holotype cranidium; dorsal and anterior views. $\times 3$.

Fig. 14. MGUH 16.304. Paratype pygidium; dorsal view. $\times 1.5$.

Fig. 15. MGUH 16.305. Paratype small pygidium; dorsal view. $\times 8$.

Fig. 16. MGUH 16.306. Paratype pygidium; dorsal view. $\times 2$. 


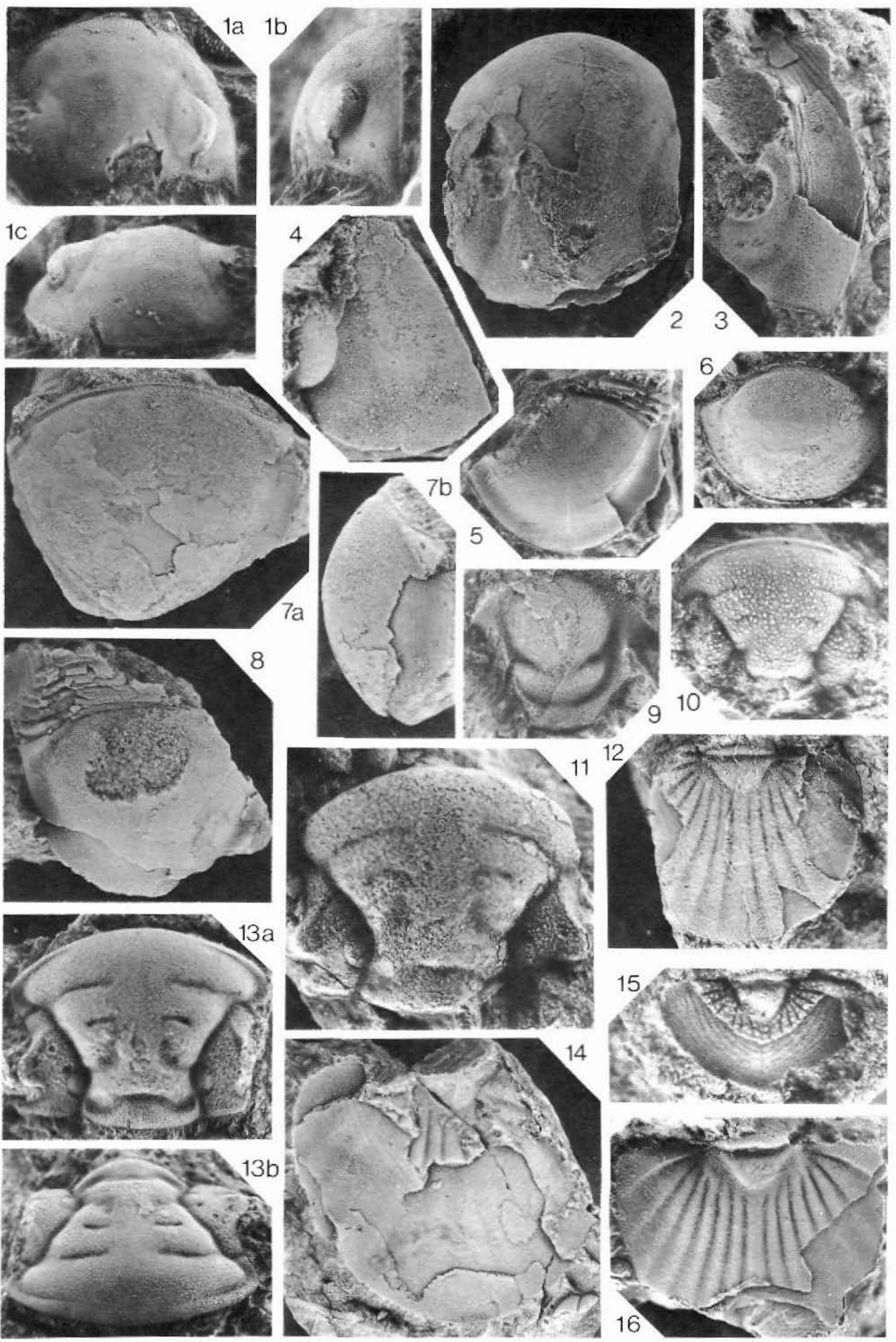




\section{Plate 2}

All specimens are from the north side of Kayser Bjerg, Hall Land, western North Greenland.

Proetus s.l. simus sp. nov.

Fig. 1a-c. MGUH 16.307. Paratype cephalon; dorsal, anterior-oblique and left-lateral views. $\times 5$.

Fig. 2a-d. MGUH 16.308. Holotype cephalon, dorsal, oblique-anterior, lateral and anterior views. $\times 5$.

Fig. 3. MGUH 16.309. Paratype seven thoracic segments and pygidium, dorsal view. $\times 5$.

Fig. 4. MGUH 16.310. Paratype pygidium; dorsal view. $\times 5$.

Fig. 5. MGUH 16.311. Latex cast of paratype pygidium; plan view. $\times 5$.

Fig. 6. MGUH 16.312. Latex cast of paratype free cheek; plan view. $\times 5$.

Fig. 7. MGUH 16.313. Paratype pygidium; dorsal view. $\times 5$.

\section{Hedstroemia sp.}

Fig. 8a, b. MGUH 16.314. Fragmentary cranidium; dorsal and anterior-oblique views. $\times 3$.

$$
\text { Proetus (s.l.) sp. }
$$

Fig. 9. MGUH 16.315. Pygidium; dorsal view. $\times 3$.

\section{Calymene sp.}

Fig. 10. MGUH 16.316. Fragmentary cranidium; dorsal view. $\times 2$.

\section{Fragiscutum? sp.}

Fig. 11. MGUH 16.317. Pygidium; dorsal view. $\times 3$.

\section{Contracheirurus errator sp. nov.}

Fig. 12a, b. MGUH 16.319. Paratype cranidium; dorsal and right-lateral views. $\times 2$.

Fig. 13. MGUH 16.321. Paratype hypostome; ventral view. $\times 3$.

Fig. 14. MGUH 16.318. Holotype pygidium; dorsal view. $\times 2$.

Fig. 15a, b. MGUH 16.320. Paratype cranidium; dorsal view. $\times 2$.

Fig. 16. MGUH 16.323. Paratype pygidium; dorsal view. $\times 2$.

Fig. 17. MGUH 16.322. Paratype pygidium; dorsal view. $\times 2$.

\section{Scotoharpes sp.}

Fig. 18. MGUH 16.324. Cephalon; dorsal view. $\times 3$. 

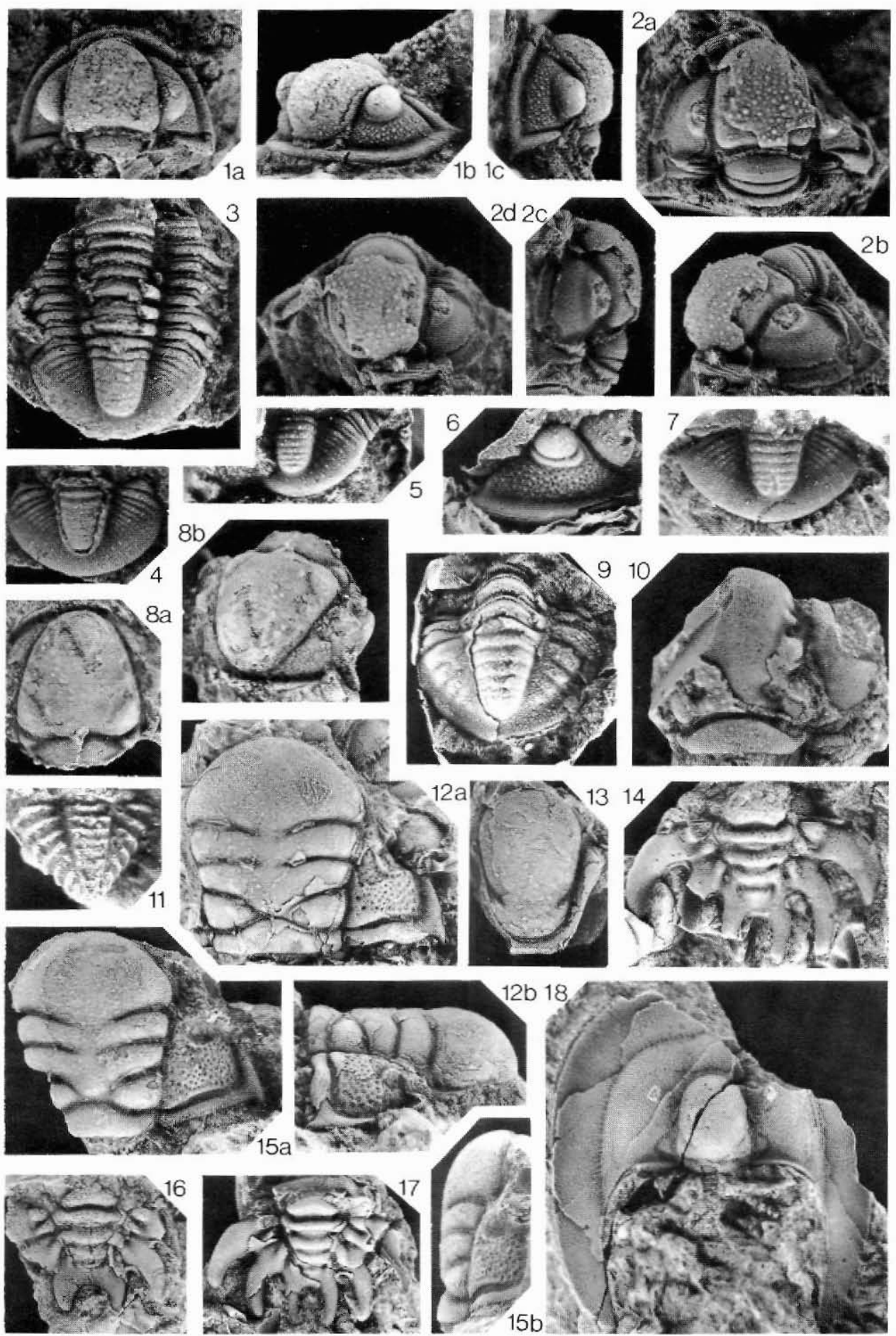


\section{Plate 3}

All specimens are from the north side of Kayser Bjerg, Hall Land, western North Greenland.

\section{Sphaerexochus dimorphus Perry \& Chatterton, 1977}

Fig. 1a, b. MGUH 16.325. Fragmentary cranidium; dorsal and left-lateral views. $\times 2$.

Fig. 2a-c. MGUH 16.326. Thoracic segment; dorsal, left-lateral and anterior-oblique views. $\times 1.5$.

Fig. 3a, b. MGUH 16.327. Fragmentary cranidium; dorsal and right-lateral views. $\times 2$.

Fig. 4. MGUH 16.328. Hypostome; ventral view. $\times 3$.

Fig. 5a-c. MGUH 16.329. Pygidium; dorsal, posterior and left-lateral views. $\times 2$.

Dicranogmus aff. D. skinneri Perry \& Chatterton, 1977

Fig. 6a-c. MGUH 16.330. Cephalon; dorsal, anterior-oblique and right-lateral views. $\times 2$.

Fig. 8. MGUH 16.331. Hypostome; ventral view. $\times 1.5$.

Fig. 10. MGUH 16.332. Cranidium; anterior view. $\times 2$.

\section{ceratargine hypostome}

Fig. 7. MGUH 16.333. Ventral view. $\times 3$.

Nonix sauroter gen. et sp. nov.

Fig. 9a, b. MGUH 16.334. Paratype cranidium; dorsal and anterior views. $\times 4$.

Fig. 11. MGUH 16.335. Paratype pygidium; ventral view. $\times 1$.

Fig. 12. MGUH 16.336. Paratype pygidium; dorsal view. $\times 1.5$.

Fig. 13. MGUH 16.337. Paratype fragmentary cranidium; dorsal view. $\times 3$.

Fig. 14. MGUH 16.338. Holotype pygidium; dorsal view. $\times 1$. 

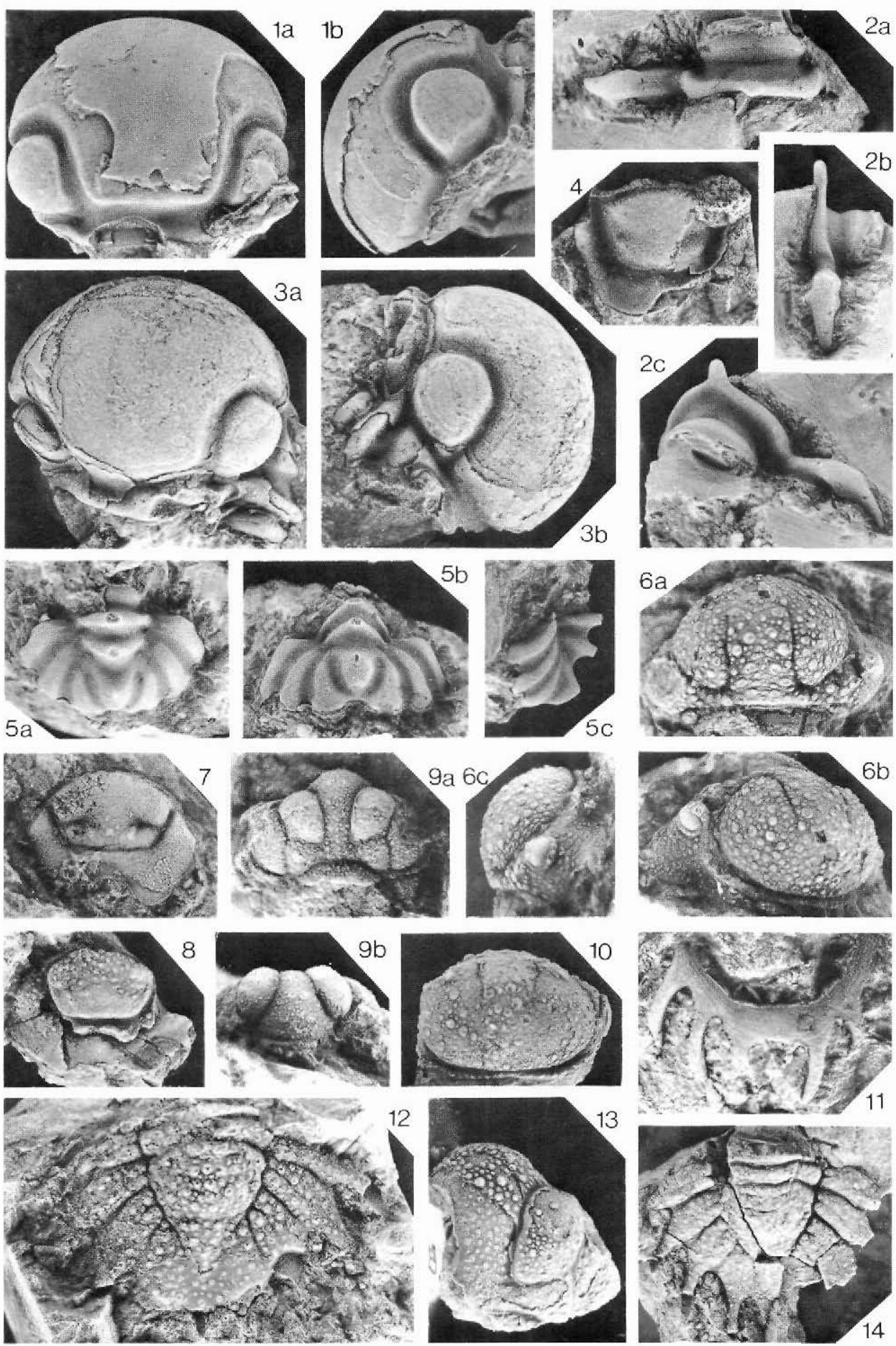


\section{Plate 4}

North-east of Korsgaard Bjerg, central Nyeboe Land

Meroperix ataphrus Lane, 1972

Fig. 1. MGUH 16.339. Cranidium; dorsal view. $\times 6$.

Fig. 2. MGUH 16.340. Pygidium; dorsal view. $\times 2$.

Chiozoon cf. cowiei Lane, 1972

Fig. 3. MGUH 16.341. Cranidium and seven thoracic segments; dorsal view. $\times 6$.

Opoa adamsi Lane, 1972

Fig. 5. MGUH 16.342. Pygidium; dorsal view. $\times 3$.

Kap Ammen, northern Hall Land

Opoa cf. O. adamsi Lane, 1972

Fig. 4. MGUH 16.343. Pygidium; dorsal view. $\times 1$.

Northern slopes of Kayser Bjerg, south-east Hall Land

Sphaerexochus cf. S. dimorphus Perry \& Chatterton, 1977

Fig. 6a, b. MGUH 16.344. Cranidium; dorsal and left-oblique views. $\times 3$.

South-west of Korsgaard Bjerg, south-west Nyeboe Land

Ligiscus cf. L. arcanus Lane \& Owens, 1982

Fig. 7. MGUH 16.345. Five thoracic segments and pygidium; dorsal view. $\times 4$.

$$
\begin{aligned}
& \text { South-east of Kap Tyson, Hall Land } \\
& \text { encrinurinid sp. indet. }
\end{aligned}
$$

Figs 8., b. MGUH 16.346. Pygidium; dorsal and left-lateral views. $\times 3$.

$$
\begin{aligned}
& \text { East side of Store Canyon, southern Nyeboe Land } \\
& \text { Bumastus sp. }
\end{aligned}
$$

Fig. 9a, b. MGUH 16.347. Cranidium; dorsal and left-oblique views. $\times 2$.

Fig. 10a-c. MGUH 16.348. Pygidium; plan, dorsal and right-lateral views. $\times 2$.

Fig. 11a-c. MGUH 16.349. Cranidium; dorsal, right-oblique and right-lateral views. $\times 2$. 

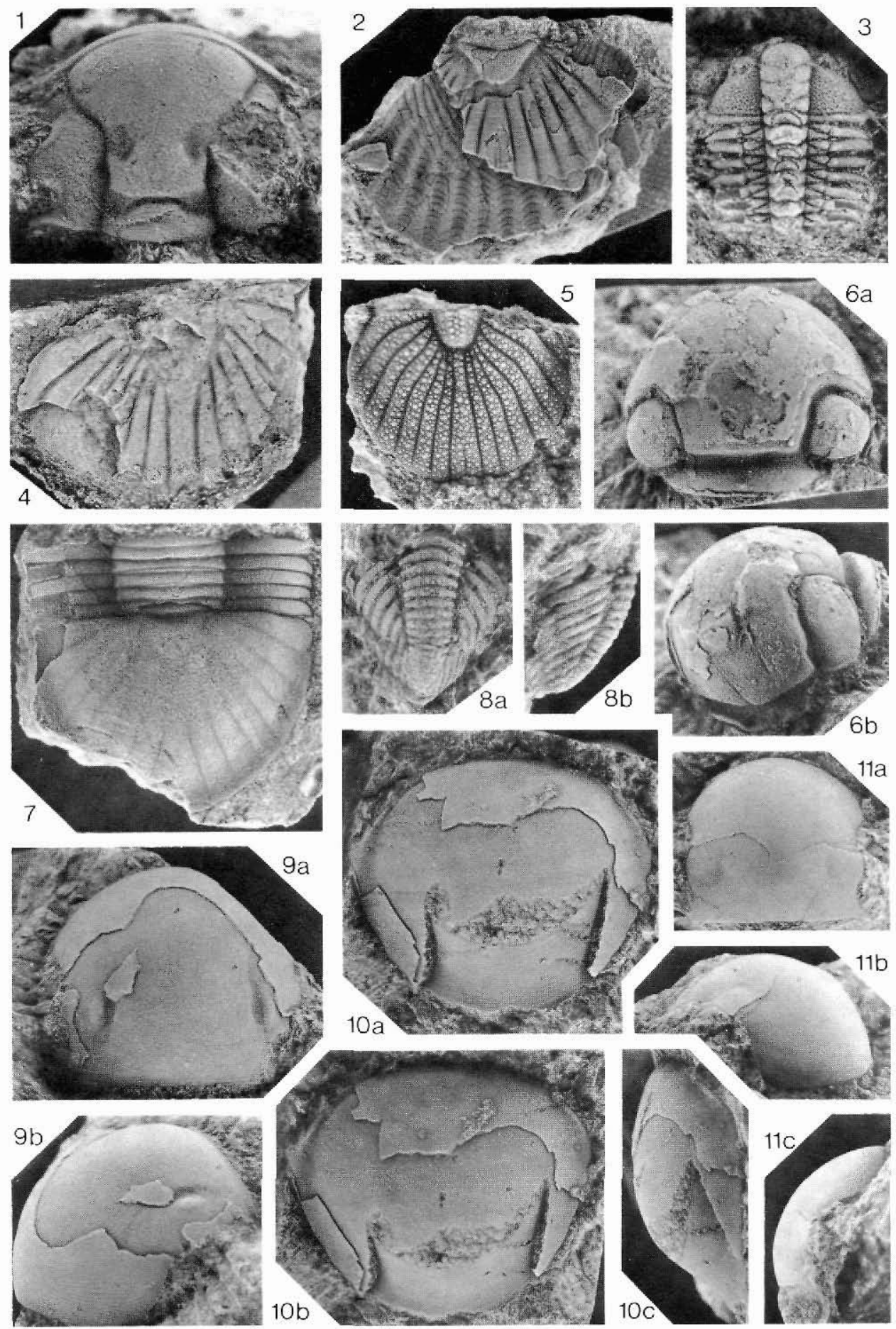

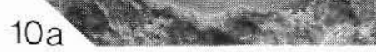

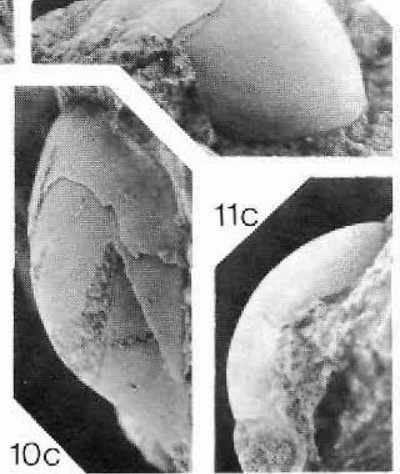

$10 b$
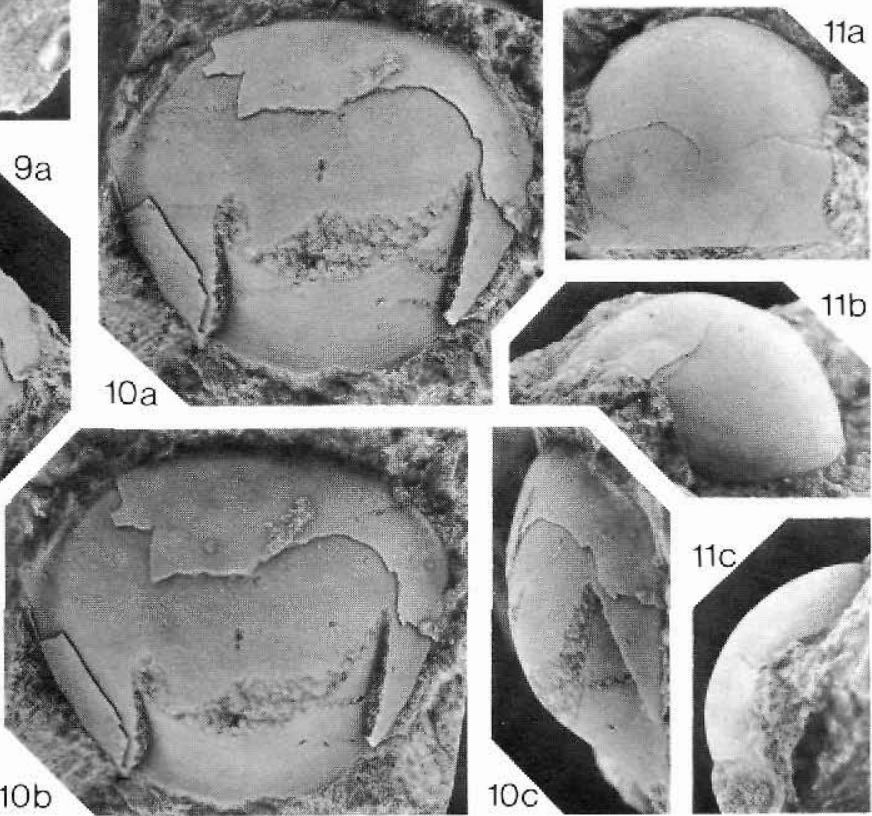